\title{
Peranan Pesantren/Ma'had Aly Makkah \\ dalam Meningkatkan Religiusitas Masyarakat Senggrong Andong Boyolali
}

\author{
Ainul Haris \\ STAI Ali bin Abi Thalib Surabaya \\ ainul.haris@stai-ali.ac.id
}

\begin{abstract}
The focus and purpose of this study is to determine the role of Aly Makkah Islamic Boarding School Senggrong Andong Boyolali in improving the religiosity of surrounding communities, and to find out the factors that support and hinder the activities of enhancing the religiosity of communities around Aly Makkah Islamic Boarding School Senggrong Andong Boyolali. This research method is descriptive qualitative with type of field research. This study found that the Aly Makkah Islamic Boarding School played an active role in improving the religiosity of the community with various religious activities. For instance, establishing a TPA (AlQur'an Learning Center), organizing a tabligh akbar, the Islamic study group after Maghrib prayer, Ramadan activities, the distribution of qurban meat, congregational prayers and Friday prayer. Some supporting factors to improve community religiosity are human resources (HR) who are energetic and play an active role in activities held by the Islamic Boarding School, adequate facilities and infrastructure, and social factors. While the inhibiting factors of Aly Makkah Islamic Boarding School in improving community religiosity include, lack of public awareness, lack of effectiveness of learning in TPA, and differences in understanding.
\end{abstract}

Keyword: Role, Islamic Boarding School, Religiosity. 


\begin{abstract}
Abstrak
Fokus dan tujuan penelitian ini yaitu untuk mengetahui peranan Ma'had/Pesantren Aly Makkah Senggrong Andong Boyolali dalam meningkatkan religiusitas masyarakat sekitar, serta untuk mengetahui faktor-faktor yang mendukung dan menghambat kegiatan peningkatkan religiusitas masyarakat sekitar Ma'had Aly Makkah Senggrong Andong Boyolali. Metode penelitian ini bersifat deskriptif kualitatif dengan jenis penelitian lapangan (field research). Penelitian ini menemukan bahwa Pesantren/Ma'had Aly Makkah berperan aktif dalam meningkatkan religiusitas masyarakat dengan berbagai kegiatan keagamaan. Di antaranya, dengan mendirikan TPA, menyelenggarakan tabligh akbar, ta'lim ba'da maghrib, kegiatan bulan Ramadhan, pembagian daging kurban, shalat jamaah dan khutbah Jum'at. Beberapa faktor pendukung untuk meningkatkan religiusitas masyarakat yaitu sumber daya manusia (SDM) yang enerjik dan berperan aktif dalam kegiatan-kegiatan yang diadakan Pesantren, sarana dan prasarana yang memadai, serta faktor sosial. Sedangkan faktor penghambat Pesantren/Ma'had Aly Makkah dalam meningkatkan religiusitas masyarakat di antaranya, kurangnya kesadaran masyarakat, kurang efektifnya pembelajaran di TPA, serta adanya perbedaan paham.
\end{abstract}

Kata Kunci: Peranan, Pesantren, Religiusitas 


\section{A. Pendahuluan}

Pesantren merupakan lembaga yang mengembangkan asas long life education. Kedudukannya sebagai lembaga pendidikan agama sekaligus lembaga sosial kemasyarakatan sungguh sangat strategis di tengah-tengah masyarakat. Apabila pesantren bisa memerankan diri dengan baik maka akan menjadi agen perubahan dan lokomotif perbaikan, khususnya di bidang keagamaan di tengahtengah masyarakat.

Secara umum, pesantren mempunyai dua fungsi utama, yaitu fungsi kegiatan tafaqquh fi addin (pengajaran, pemahaman dan pendalaman ajaran Islam) dan fungsi indzar (menyampaikan dan mendakwahkan Islam kepada masyarakat) ${ }^{92}$. Sepanjang sejarah perjalanan umat Islam Indonesia, ternyata kedua fungsi utama tersebut telah dilaksanakan oleh pesantren pada umumnya.

Pengaruh sebuah pesantren yang ada di lingkungan suatu masyarakat dapat dilihat dari segi moral, akhlak, gaya hidup, bahkan perekonomian masyarakat sekitar pesantren yang jelas berbeda dari masyarakat yang tidak tinggal berdekatan dengan pesantren. Religius atau bersifat agamis didefinisikan sebagai perilaku yang patuh dalam menjalankan ajaran agama yang dianut, toleran terhadap pelaksanaan agama lain. Karakter religius ini sangat dibutuhkan masyarakat untuk menghadapi perubahan zaman dan degradasi moral.

Pondok pesantren melahirkan para juru dakwah, mu'allim, ustadz dan kyai serta tokoh masyarakat dengan berbagai profesi seperti pedagang, pengusaha dan sebagainya, sehingga pesantren sesungguhnya merupakan lembaga pendidikan yang lengkap sebagai bekal untuk hidup di tengah-tengah masyarakat.

Ma'had Aly Makkah merupakan salah satu jenis pesantren tinggi yang terletak di desa Senggrong Kecamatan Andong Boyolali. Ma'had Aly Makkah tidak hanya berperan di dalam mentransmisikan ilmu-ilmu Islam kepada para santrinya, tetapi juga berperan dalam meningkatkan nilai religius masyarakat sekitarnya.

Keterkaitan kegiatan santri dengan masyarakat terutama pengaruhnya terhadap kegiatan religi, baik secara langsung maupun tidak langsung terhadap kehidupan masyarakat membawa dampak tersendiri terhadap kehidupan masyarakat sekitar. Kegiatan shalat jama'ah di masjid pesantren, pengajaran anak-anak TPA di masjidmasjid sekitar pesantren, shalat Jum'at, bantuan buka puasa bersama dari Ma'had Aly Makkah ke masjid-masjid sekitar, kegiatan pengajian

92 Didin Hafidhuddin, Dakwah Aktual, (Jakarta: Gema Insani Press, 2000), hlm. 120121. 
umum atau tabligh akbar di Ma'had Aly Makkah dinilai memberikan pengaruh positif terhadap religiulistis masyarakat sekitar Ma'had Aly Makkah.

\section{B. Tinjauan Teori}

Peranan adalah bagian dari tugas utama yang harus dilakukan oleh seseorang dalam manajemen, pola penilaian yang diharapkan dapat menyertai suatu status bagian atau fungsi seseorang dalam kelompok atau pranata, fungsi yang diharapkan dari seseorang atau menjadi karakteristik yang ada padanya dan fungsi setiap variabel dalam hubungan sebab akibat. ${ }^{93}$

Menurut Soerjono Soekanto, peranan merupakan aspek yang dinamis dari kedudukan (status). Apabila seseorang melaksanakan hak dan kewajibannya sesuai dengan kedudukannya maka hal ini berarti ia menjalankan suatu peranan. Keduanya tidak dapat dipisahpisahkan satu sama lain. Setiap orang mempunyai macam-macam peranan yang berasal dari pola-pola pergaulan hidupnya. Hal tersebut sekaligus berarti bahwa peranan menentukan apa yang diperbuatnya bagi masyarakat kepadanya. Peranan lebih banyak menekankan pada fungsi, penyesuaian diri dan sebagai suatu proses. ${ }^{94}$

Pesantren merupakan suatu lembaga pendidikan agama Islam yang tumbuh serta diakui masyarakat sekitar, dengan sistem asrama (komplek) di mana santri-santri menerima pendidikan agama melalui sistem pengajian atau madrasah yang sepenuhnya berada di bawah kedaulatan dari leadership seorang atau beberapa orang kiai dengan ciri-ciri khas yang bersifat kharismatik serta independen dalam segala hal. ${ }^{95}$ Suatu tempat yang tersedia untuk para santri dalam menerima pelajaran-pelajaran agama Islam sekaligus tempat berkumpul dan tempat tinggalnya. ${ }^{96}$

Tujuan pendidikan pesantren harus sejalan dengan tujuan hidup manusia menurut Islam. Sebab pendidikan hanyalah cara yang ditempuh agar tujuan hidup itu dapat dicapai. Jika tujuan hidup manusia yaitu mengembangkan pikiran manusia dan mengatur tingkah laku serta perasaannya berdasarkan Islam, demikian juga tujuan pendidikan Islam. Keberadaan pesantren adalah untuk merealisasikan

\footnotetext{
${ }^{93}$ Komarudin, Ensiklopedia Manajemen, (Jakarta: Bumi Aksara, 2001), hlm. 78.

94 Soerjono Soekanto, Sosiologi suara pengantar, (Jakarta: Raja Grafindo Persada, 2002), hlm. 268-269.

95 M. Arifin, Kapita Selekta Pendidikan (Islam dan Umum), (Jakarta: Bumi Askara, 1991), hlm. 240.

${ }^{96}$ Lembaga Research Islam (Pesantren Luhur), Sejarah dan Dakwah Islamiyah Sunan Giri, (Malang: Panitia Penelitian dan Pemugaran Sunan Giri Gresik, 1975), hlm. 52.
} 
ubudiah kepada Allah di dalam kehidupan manusia, baik individu maupun masyarakat. ${ }^{97}$

Pesantren sesungguhnya bisa mengambil peran lebih besar daripada apa yang telah diperbuatnya selama ini. Memang benar bahwa tugas pokok yang dipikul pesantren selama ini pada esensinya adalah mewujudkan manusia dan masyarakat muslim Indonesia yang bertakwa kepada Allah SWT. Dalam kaitannya pesantren bahkan diharapkan lebih dari pada itu, ia diharapkan dapat memikul tugas yang tak kalah pentingnya yaitu melakukan reproduksi ulama. Para santri diharapkan mampu membangun dirinya dan masyarakat sekelilingnya, dapat memainkan fungsi ulama, yang biasanya pengakuan terhadap fungsi keulamaan mereka pelan-pelan tapi pasti datang dari masyarakat. ${ }^{98}$

Religiusitas sendiri dapat dipahami sebagai penghayatan dan keyakinan terhadap Tuhan dan agama yang diwujudkan dengan mematuhi perintah dan menjauhi larangan yang ada di dalam suatu agama dengan sepenuh hati. Religiusitas atau sikap keagamaan yang dimiliki oleh seorang individu terbentuk oleh tradisi keagamaan. Religiusitas merupakan bagian dari pernyataan jati diri individu tersebut dalam kaitan dengan agama yang dianutnya. Religiusitas ini akan ikut mempengaruhi cara berfikir, cita rasa, ataupun penilaian seseorang terhadap sesuatu yang berkaitan dengan agama. ${ }^{99}$

Seorang muslim dengan tingkat religiusitas tinggi akan berusaha menjalankan Islam secara kaffah (menyeluruh). Islam kaffah haruslah mencakup seluruh aspek kehidupan, baik bersifat ritual (ibadah) maupun sosial kemasyarakatan (muamalah). Ibadah diperlukan untuk menjelaskan hakikat hidup manusia sebagai hamba Allah maupun khalifah di muka bumi. Muamalah merupakan rules of game bagi manusia dalam kehidupan sosial tanpa memandang apapun. Aspek yang harus diperhatikan agar bisa menjalani kehidupan Islami secara kaffah. Muamalah tersebut mencakup antara lain politik islami, ekonomi islami, budaya islami dan hukum islami. ${ }^{100}$

Faktor-faktor yang mempengaruhi sikap keagamaan (religiusitas) ada empat macam, yaitu:

\footnotetext{
${ }^{97}$ Kompri, Manajemen dan Kepemimpinan Pondok Pesantren, (Jakarta: Prenadamedia Group, 2018), hlm. 5

${ }^{98}$ Babun Suharto, Dari Pesantren untuk Umat Reinventing Eksistansi Pesantren di Era Globalisasi, (Surabaya: Imtiyaz, 2011), hlm. 70.

${ }^{99}$ Jalaludin, Psikologi Agama, (Jakarta: Raja Grafindo Persada, 2001), hlm.191.

${ }^{100}$ Muhammad Syafi'i Antonio, Bank Syariah dari Teori ke Praktek, (Jakarta: Gema Insani Press, 2001),hlm. 2-6.
} 
a. Pengaruh pendidikan atau pengajaran dan berbagai tekanan sosial

Faktor ini mencakup semua pengaruh sosial dalam perkembangan keagamaan itu, termasuk pendidikan dari orang tua, tradisi-tradisi sosial, tekanan dari lingkungan sosial untuk menyesuaikan diri dengan berbagai pendapat dan sikap yang disepakati oleh lingkungan itu.

b. Faktor Pengalaman

Faktor pengalaman berkaitan dengan berbagai jenis pengalaman yang membentuk sikap-sikap keagamaan. Terutama pengalaman mengenai keindahan, konflik moral dan pengalaman emosional keagamaan. Faktor ini umumnya berupa pengalaman spiritual yang secara cepat dapat mempengaruhi perilaku individu.

c. Faktor Kehidupan

Kebutuhan-kebutuhan manusia secara garis besar dapat dibagi menjadi empat, yaitu kebutuhan akan keamanan atau keselamatan, kebutuhan akan cinta kasih, kebutuhan untuk memperoleh harga diri, kebutuhan yang timbul karena adanya ancaman kematian.

\section{d. Faktor Intelektual}

Faktor intelektual berkaitan dengan berbagai proses penalaran verbal atau rasionalisasi. Berdasarkan penjelasan di atas dapat disimpulkan bahwa setiap individu berbeda-beda tingkat religiusitasnya. Secara garis besarnya ia dipengaruhi oleh dua macam faktor yaitu faktor internal dan eksternal. Faktor internal yang dapat mempengaruhi religiusitas antara lain adanya pengalaman-pengalaman emosional keagamaan, kebutuhan individu yang mendesak untuk dipenuhi seperti kebutuhan akan rasa aman, harga diri, cinta kasih dan sebagainya. Sedangkan pengaruh eksternalnya seperti pendidikan formal, pendidikan agama dalam keluarga, tradisitradisi sosial yang berlandaskan nilai-nilai keagamaan, dan tekanan-tekanan lingkungan sosial dalam kehidupan individu.

Religuisitas seseorang (kereligiusan) dapat mempengaruhi penilaian individu, keyakinan dan perilaku dalam berbagai situasi. Religiusitas memiliki pengaruh, baik pada sikap maupun perilaku manusia. Religiusitas merupakan nilai penting dalam 
struktur kognitif individu yang dapat mempengaruhi perilaku dirinya. ${ }^{101}$

Keyakinan beragama menjadi bagian yang integral dari kepribadian seseorang. Keyakinan itu akan mengawasi segala tindakan, perkataan bahkan perasaan. Pada saat seseorang tertarik pada sesuatu yang tampaknya menyenangkan maka keimanannya akan cepat bertindak menimbang dan meneliti apakah hal tersebut boleh atau tidak oleh agamanya.

Agama adalah iman akan adanya kekuasaan tak terbatas, atau kekuasaan yang tidak bisa digambarkan batas waktu atau tempatnya. James Redfield, dalam bukunya mengenai pengantar sejarah agama mengatakan bahwa keberagamaan adalah pengarahan manusia agar tingkah lakunya sesuai dengan perasaan tentang adanya hubungan antara jiwanya dan jiwa yang tersembunyi, yang diakui kekuasaannya atas dirinya dan atas sekalian alam, dan dia rela merasa berhubungan seperti itu. Muhaimin menjelaskan, mestinya orang yang beragama itu adalah religius juga, yaitu menaati ajaran agamanya. ${ }^{102}$

\section{Metode Penelitian}

Jenis penelitian yang digunakan dalam penelitian ini merupakan jenis penelitian lapangan (field research) dan bersifat deskriptif kualitatif. Sumber data diperoleh dengan sumber data primer dan sekunder. Sumber data primer diperoleh langsung dari sumber utamanya, yakni dengan menggunakan informasi yang diperoleh dari sumber yang dapat menjelaskan masalah berkaitan dengan Peran Ma'had Aly Makkah Senggrong Andong Boyolali, baik dari internal pondok maupun masyarakat sekitar. Sumber data sekunder diambil dari perpustakaan, gambar, dokumen dan sumbersumber lain yang tentunya sangat membantu terkumpulnya data.

Metode pengumpulan data yang digunakan untuk mengkaji masalah dalam penelitian ini yaitu observasi, wawancara dan dokumentasi. Dalam pengelolaan data penelitian dan keakuratan sebuah data, peneliti menginterpretasikan data hasil observasi yang diperoleh dari Ma'had Aly Makkah Boyolali dengan cara menganalisa makna yang tersirat di dalam data tersebut, kemudian dilanjutkan dengan kualifikasi data yang diperlukan dan telah sesuai

${ }^{101}$ Jalaluddin, Psikologi Agama, (Jakarta: PT. Raja Grafindo Persada, 1997), hlm. 6061.

102 R. Diana, Hubungan Antara Religiusitas dan Kreatifitas Siswa Sekolah Menengah Umum, Jurnal Psikologi. No.7.thn.III, Yogyakarta, 1999, hlm.10 
dengan peranan Pesantren/Ma'had Aly Makkah dalam meningkatkan religiusitas masyarakat Sengrong Andong Boyolali.

\section{Hasil Penelitian}

Peran pesantren cukup signifikan dalam memberikan sumbangsih dalam meningkatkan keagamaan masyarakat. Dalam kehidupan bermasyarakat terdapat sistem nilai, baik nilai keswadayaan, kemandirian, sosial maupun nilai politis.

Peran Pesantren sebagai lembaga dakwah dapat dilihat dari kegiatannya dalam melakukan dakwah di kalangan masyarakat, aktifitasnya yang menumbuhkan kesadaran beragama dan melaksanakan ajaran-ajaran agama secara konsekuen sebagai pemeluk agama Islam. Keberadaan pesantren di tengah masyarakat bertujuan menegakkan kalimat Allah, menyebarkan ajaran agama Islam agar pemeluknya memahami Islam dengan sebenarnya. Fungsi Pesantren sebagai lembaga sosial ditunjukkan dalam keterlibatan pesantren menangani beberapa masalah sosial yang dihadapi oleh masyarakat, Pesantren bukan saja sebagai lembaga pendidikan dan dakwah, tetapi lebih jauh daripada itu ada kiprah sosial yang besar dari pesantren yang dipersembahkan untuk masyarakatnya.

Secara kelembagaan, pesantren telah memberikan tauladan nyata dan kongkrit dengan mengaktualisasikan semangat indzar atau menyeru kepada jalan agama dengan diadakannya kegiatan yang melibatkan masyarakat sekitar khususnya dan masyarakat umum. Secara umum pengembangan berbagai kegiatan ini dimaksudkan untuk memperkuat fungsi pesantren, sebagai sarana belajar dan berlatih bagi para santri dan untuk mengembangkan nilai spiritual masyarakat

Dilihat dari latar belakang lingkungan pesantren, sesungguhnya Ma'had Ali Makkah berdiri di tengah lingkungan masyarakat yang kurang dalam hal pemahaman dan pengamalan agamanya, bahkan sebagiannya merupakan orang-orang abangan (baca: jauh dari agama), hal yang meniscayakan tingkat kesadaran yang rendah untuk belajar dan mengamalkan agama.

Kegiatan-kegiatan yang digagas oleh Ma'had Aly Makkah beberapa di antaranya melibatkan masyarakat sekitar pesantren khususnya dan masyarakat umum. Kegiatan ini diselenggarakan dengan tujuan untuk membawa perubahan positif dalam segi religi masyarakat.

Adapun beberapa kegiatan Ma'had Aly Makkah Boyolali yang melibatkan masyarakat di antaranya: 
1. Mendirikan Taman Pendidikan Al-Qur'an (TPA)

TPA tersebut didirikan mengingat pentingnya kemampuan baca tulis Al-Quran dan minimnya kemampuan yang dimiliki kalangan masyarakat, khususnya anak-anak. Kegiatan ini, selain membawa misi pengajaran al-Qur'an sesuai dengan kaidah tajwid, tentu sekaligus membuka peluang dakwah pesantren untuk menyebarkan ilmu agama di kalangan masyarakat sekitar pesantren.

Ma'had Aly Makkah bekerja sama dengan masjid-masjid sekitar mendirikan dan membina 9 TPA yang kesemuanya berada di lingkungan sekitar pesantren. Kegiatan mahasantri mengajar di TPA binaan tersebut berada di bawah koordinasi Bagian Dakwah HIMMAH (Himpunan Mahasantri Ma'had Makkah). Kegiatan ini diwajibkan untuk mahasantri yang sudah menginjak semester 3 dan 4. Kegiatan belajar mengajar TPA berlangsung selama 4 hari setiap pekannya. Adapun pelajaran yang di ajarkan para mahasantri yaitu Al -Qur'an, Ibadah, Adab dan Do'a.

Selain mendirikan dan membina TPA, Ma'had Aly Makkah juga menyelenggarakan lomba yang diadakan setiap tahun menjelang bulan Ramadhan. Lomba ini diikuti oleh segenap TPA binaan Ma'had Aly Makkah dan TPA-TPA di luar binaan. Adapun kegiatan yang dilombakan di antaranya adzan, hafalan ayat-ayat pendek, mewarnai, dan hafalan doa-doa sehari-hari. Dari kegiatan ini dipilih juara 1,2,3 dan juara harapan.

\section{Tabligh Akbar}

Secara mendasar seluruh kegiatan pesantren, baik di dalam maupun di luar pesantren merupakan bentuk kegiatan dakwah. Sebab pada hakikatnya pesantren berdiri tak lepas dari tujuan dakwah secara umum. Dakwah merupakan aktivitas yang bersifat urgen di dalam agama Islam, karena dengan dakwah Islam dapat tersebar serta diterima oleh masyarakat, dakwah juga berfungsi untuk menata kehidupan yang agamis menuju keharmonisan dan kebahagiaan masyarakat. ${ }^{103}$

Salah satu bentuk dakwah yang diadakan Ma'had Aly Makkah di antaranya dengan menyelenggarakan tabligh akbar dengan mendatangkan para dai dari luar daerah. Terkadang kegiatan yang diadakan tiga bulan sekali ini juga dikemas dalam bentuk kegiatan-kegiatan ilmiah. Di antaranya seperti daurah

${ }^{103}$ M. Ali Aziz, Ilmu Dakwah, (Jakarta: Kencana, 2004), hlm. 37. 
(training ilmu-ilmu keislaman), diskusi dan seminar keagamaan. Kegiatan ini dihadiri oleh tokoh dan masyarakat setempat, serta para mahasantri. Dari berbagai kegiatan tersebut disarikan pokokpokok materinya lalu diproduksi rekaman atau video, kemudian dishare di media sosial seperti youtube, instagram, facebook dan lainnya agar dapat dinikmati manfaatnya oleh masyarakat secara luas.

\section{Kegiatan Selama Bulan Ramadhan}

Kegiatan selama Ramadhan di antaranya ada kegiatan buka bersama dan shalat tarawih di masjid Ma'had Aly Makkah. Kegiatan buka bersama yang dilakukan selama satu bulan penuh ini dihadiri oleh masyarakat sekitar, kemudian dilanjutkan dengan shalat Maghrib berjamaah.

Selain menyelenggarakan buka puasa di masjid Mah'ad, buka puasa juga diselenggarakan di 12 masjid dan musholla sekitar Ma'had yang dananya merupakan bantuan donatur yang disalurkan melalui Ma'had Aly Makkah. Kegiatan buka puasa di masjidmasjid tersebut adalah hal baru bagi masyarakat, sehingga menjadi daya tarik tersendiri bagi masyarakat untuk datang ke masjid dan menjadi salah satu syiar bulan Ramadhan yang semarak di lingkungan masjid-masjid tersebut.

Adapun shalat tarawih, dilakukan langsung selepas sholat Isya' yang diikuti oleh warga pondok pesantren dan masyarakat sekitar dengan jumlah 11 rakaat. Shalat tarawih diimami oleh mahasantri Ma'had secara bergantian setiap malamnya.

4. Pembagian Daging Kurban

Kegiatan ini dilaksanakan pada hari raya Kurban (Idul Adha). Masyarakat ikut bergotong-royong menyembelih hewan kurban bersama dewan guru dan segenap mahasantri. Selain untuk dikonsumsi oleh warga pondok, daging kurban itu juga didistribusikan kepada warga masyarakat sekitar. Untuk menjalin keakraban dengan warga sekitar pembagian daging kurban tersebut dilakukan oleh para mahasantri yang mendapatkan mandat dari Ma'had Ali. Para mahasantri tersebut mengantarkan daging kurban yang sudah dikemas dengan kadar berat yang sama ke rumahrumah warga masyarakat sekitar.

5. Sholat Jum'at dan Khutbah Jum'at

Setiap hari Jum'at, warga Ma'had Aly Makkah dan masyarakat sekitar melaksanakan shalat Jum'at di masjid Ma'had. 
Adapun yang menjadi petugas imam dan khotib, para asatidz biasanya menunjuk mahasantri Ma'had Aly Makkah secara bergilir. Hal ini dilakukan dengan tujuan agar mahasantri melatih keterampilan dan membiasakan diri berkhutbah. Memiliki keahlian khutbah Jum'at dan ceramah secara umum adalah penting, sebagai kaderisasi dan regenerasi da'i agar dapat melanjutkan dakwah serta syiar Islam di tengah-tengah masyarakat.

Setelah selesai sholat Jum'at, untuk menjalin keakraban dengan warga masyarakat sekitar, warga Ma'had kadang-kadang memberikan suguhan minumam atau makanan kecil, sehingga lebih akrab ketika bercengkerama dan berbincang-bincang dengan mereka.

\section{Ta'lim Ba'da Maghrib}

Bentuk dakwah lain yang dilakukan Ma'had Aly Makkah yaitu ta'lim $b a$ 'da Maghrib. Kegiatan ini dilakukan langsung setelah shalat Maghrib berjama'ah di masjid Ma'had Aly Makkah, yang diikuti oleh warga Ma'had Aly Makkah serta masyarakat sekitar Ma'had. Berbeda dengan khatib shalat Jum'at, ta'lim ini diampu dan diajar langsung oleh para asatidz.

Adapun pembahasan ta'lim terdiri dari kitab al-Ushul alTsalatsah (Pembahasan Tauhid), Shohih Fiqh Sunnah (Fiqh Perbandingan Madzhab), Hilyah Thulabi al-Ilmi (Adab dan Motivasi Menuntut Ilmu), Adhwa' al-Bayan (Tafsir Al-Qur'an), al-Irsyad Ila Shahih al-I'tiqod (Aqidah Ahlus Sunnah wal Jamaah), serta Tahsin Al-Qur'an.

Berdasarkan pengamatan, observasi dan wawancara yang dilakukan di lapangan, terdapat faktor pendukung kegiatan Pesantren/Ma'had Aly Makkah dalam meningkatkan religiusitas masyarakat, di antaranya sebagai berikut:

1. Sumber Daya Manusia (SDM)

Sumber Daya Manusia (SDM) yang dimaksud di sini adalah warga Pesantren dan masyarakat sekitar yang berperan aktif dalam kegiatan-kegiatan yang diadakan Pesantren. Faktor SDM dinilai menjadi faktor yang sangat dominan untuk mendukung berbagai kegiatan dalam meningkatkan religiusitas masyarakat sekitar. Para mahasantri dan dewan guru berperan aktif dalam setiap kegiatan yang diselenggarakan pesantren, sehingga mayoritas kegiatan tersebut tergolong sukses dalam mengajak dan melibatkan masyarakat sekitar. Selain itu kehandalan strategi SDM Ma'had juga teruji dengan keberhasilan 
mereka melibatkan tokoh-tokoh masyarakat dalam berbagai kegiatan yang diselenggarakan, seperti tabligh akbar, ta'lim, daurah (training ilmu-ilmu keislaman), penyembelihan hewan kurban dan kegiatan lainnya.

2. Sarana dan Prasarana

Adanya sarana dan prasarana untuk menunjang terselenggaranya bermacam kegiatan terutama yang berhubungan dengan masyarakat sangatlah penting, karena dapat mempermudah suatu proses pelaksanaan kegiatan, sehingga tujuannya dengan mudah dapat tercapai.

Sarana dan prasarana yang memadai dan telah dikelola oleh Pesantren/Ma'had Aly Makkah untuk berbagai kegiatan dalam rangka meningkatkan religiusitas masyarakat sekitar di antaranya seperti aula pertemuan, masjid, kelas, kantor dan lapangan. Sebagian bangunan gedung tersebut dilengkapi dengan air conditioner (AC), sehingga lebih sejuk, nyaman dan kondusif untuk penyelenggaraan berbagai kegiatan yang melibatkan masyarakat sekitar.

\section{Faktor Sosial}

Menjalin hubungan sosial yang baik dengan masyarakat sekitar akan mewujudkan kehidupan yang harmoni, rasa tanggung jawab bersama, serta menjadi faktor penting bagi terciptanya situasi dan kondisi yang saling menghargai dan menghormati. Adanya Ma'had Aly Makkah diakui atau tidak menjadi berkah tersendiri bagi masyarakat sekitar, khususnya dalam melakukan kegiatan-kegiatan yang berhubungan dengan lingkungan. Ma'had Aly Makkah -sebagai bentuk kepeduliannya terhadap lingkungan- seringkali memberikan bantuan finansial kepada masyarakat untuk berbagai keperluan lingkungan seperti untuk pembangunan gerbang jalan, renovasi musholla, pembangunan kamar mandi dan WC masjid dan lain-lain.

Adapun aktifitas keseharian yang sering dilakukan dengan melibatkan masyarakat sekitar di antaranya adalah kerja bakti dan gotong royong menjaga kebersihan lingkungan, khususnya di sepanjang jalan yang menghubungkan ke area Ma'had Aly Makkah. Selain itu, warga Ma'had yang diwakili oleh sebagian dewan guru juga aktif menghadiri rapat-rapat yang diselenggarakan oleh aparatur pemerintah desa, kecamatan atau ormas-ormas yang berada di wilayah kecamatan Andong Boyolali. Pihak Ma'had Aly juga menjaga hubungan silaturahim 
yang baik dengan aparat pemerintah terkait, seperti dengan Kepala Desa Senggrong, Kepala Desa Kacangan, Kapolsek Andong, dan sebagainya.

Selain faktor pendukung, ada juga faktor penghambat dalam pelaksanaan kegiatan peningkatan religiusitas masyarakat, di antaranya sebagai berikut:

1. Kurangnya Kesadaran

Dalam hal ini kesadaran akan pentingnya shalat berjama'ah maupun ta'lim masih kurang, terutama para remaja sehingga masjid sebagian besar hanya diisi oleh orangtua saja. Selain itu remaja sekitar Pesantren masih banyak yang terlena dengan pergaulan bebas, bahkan masih ada yang suka mabuk-mabukan. Adanya organisasi yang aktif untuk remaja, yakni Karang Taruna hanya untuk kegiatan yang bersifat sosial, tidak di sangkutpautkan dengan kegiatan yang berhubungan dengan keagamaan.

2. Kurang Efektifnya Pembelajaran di TPA

Ada beberapa faktor yang mempengaruhi kurang efekifnya kegiatan pembelajaran di TPA yang dilaksanakan di berbagai masjid, di antaranya: a. Para orang tua kurang memperhatikan dan memotivasi anak-anak mereka untuk belajar Al-Qur'an, juga kurang menanamkan sikap hormat kepada guru, sehingga sebagian murid TPA berprilaku kurang baik dan malas mengaji. Di sisi lain, pembelajaran di TPA waktunya sangat terbatas, sehingga tidak memungkinkan mahasantri yang mengajar TPA terus-menerus memperhatikan dan mengawasi murid-murid mereka di luar jam-jam TPA. b. Beberapa masjid ada yang kekurangan sarana dan prasarana, karena setiap TPA berada di masjid yang berbeda. c. Sebagian murid mengantuk bahkan ada yang tidur karena terbentur jam pulang sekolah yang sangat berdekatan dengan waktu masuk TPA. d. Sebagian guru dari mahasantri kekurangan alat transportasi.

\section{Perbedaan Paham}

Sebagian masyarakat Desa Senggrong Andong masih berpikir tradisional dan kurang terbuka dengan wawasan pemikiran Islam yang luas. Sebagian mereka hanya menjalankan agama sesuai dengan tradisi dan tidak peduli apakah yang mereka jalankan telah sesuai dengan Al-Qur'an dan Hadits atau tidak. Demikian juga dalam hal cara memahaminya, mereka tidak 
mempedulikan apakah sudah sesuai dengan pemahaman salafus shalih atau tidak, suatu pemahaman agama yang sesuai dengan pemahaman tiga generasi terbaik yang direkomendasikan oleh Nabi Shallallahu Alaihi wa Sallam, yaitu para sahabat, tabiin dan tabiut tabiin.

Sebagian masyarakat juga ada yang tidak mau memahami misi dakwah yang dibawa oleh Ma'had Aly Makkah. Sebagian masyarakat menganggap bahwa ajaran yang dibawa oleh Ma'had Aly Makkah berbeda dengan yang mereka pahami selama ini, sehingga mereka terkesan berhati-hati dalam menerima pengajaran dari mahasantri Ma'ad Aly. Hal itu terbukti dengan adanya pembatasan penyampaian materi untuk anak-anak TPA, sehingga mahasantri kurang leluasa dalam menyampaikan misi dakwahnya, karena terbentur oleh pemahaman yang dianggap berbeda.

\section{E. Kesimpulan}

Berdasarkan hasil penelitian yang telah diuraikan di atas maka dapat disimpulkan beberapa hal berikut ini:

1. Peranan Pesantren/Ma'had Aly Makkah dalam meningkatkan religiusitas masyarakat selain dalam bentuk membekali santri dengan ilmu teori maupun praktik juga dengan mengajak masyarakat untuk belajar dan melakukan pembinaan keagamaan. Adapun beberapa kegiatan yang dilakukan di antaranya adalah mendirikan TPA, tabligh akbar, ta'lim ba'da maghrib, kegiatan bulan Ramadhan, pembagian daging kurban, shalat jamaah dan khutbah jum'at.

2. Faktor pendukung kegiatan Pesantren/Ma'had Aly Makkah dalam meningkatkan religiusitas masyarakat di antaranya terdiri dari Sumber Daya Manusia (SDM) yang berperan aktif dalam kegiatan-kegiatan yang diadakan Pesantren, sarana dan prasarana yang memadai, serta faktor sosial. Sedangkan faktor penghambat Ma'had Aly Makkah dalam meningkatkan religiusitas masyarakat di antaranya terdiri dari kurangnya kesadaran, kurang efektifnya pembelajaran di TPA, serta adanya perbedaan paham. 


\section{F. Daftar Pustaka}

Antonio, Muhammad Syafi'i. 2001. Bank Syariah dari Teori ke Praktek. Jakarta: Gema Insani Press.

Arikunto, Sarjono. 1982. Sosiologi Suatu Pengantar. Jakarta: UI Press. Grafindo Persada.

Arifin, M. 1991. Kapita Selekta Pendidikan (Islam dan Umum). Jakarta: Bumi Askara.

Aziz, M. Ali. 2004. Ilmu Dakwah. Jakarta: Kencana.

Diana, R. 1999. Hubungan Antara Religiusitas dan Kreatifitas Siswa Sekolah Menengah Umum. Jurnal Psikologi No.7.thn.III, Yogyakarta.

Hafidhuddin, Didin. 2000. Dakwah Aktual. Jakarta: Gema Insani Press.

Jalaluddin. 1997. Psikologi Agama. Jakarta: PT. Raja Grafindo Persada.

Komarudin. 2001. Ensiklopedia Manajemen. Jakarta: Bumi Aksara.

Kompri. 2018. Manajemen dan Kepemimpinan Pondok Pesantren. Jakarta: Prenadamedia Group.

Lembaga Research Islam (Pesantren Luhur). 1975. Sejarah dan Dakwah Islamiyah Sunan Giri. Malang: Panitia Penelitian dan Pemugaran Sunan Giri Gresik.

Suharto, Babun. 2011. Dari Pesantren untuk Umat Reinventing Eksistensi Pesantren di Era Globalisasi. Surabaya: Imtiyaz. 